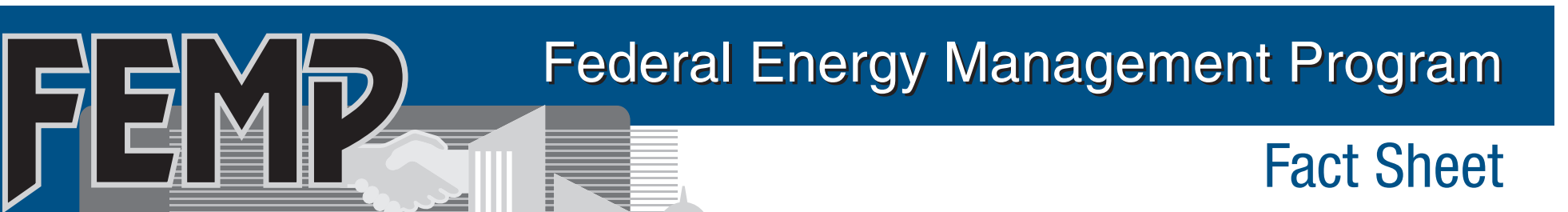

Leading by example, saving energy and taxpayer dollars in federal facilities

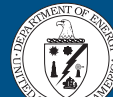

U.S. Department of Energy Energy Efficiency and Renewable Energy Bringing you a prosperous future where energy is clean, abundant, reliable, and affordable

\title{
Do you want to reach your agency's energy efficiency goals?
}

The Federal Utility Partnership Working Group (FUPWG) can help you!

FUPWG brings together Federal agencies and utilities to identify, develop, and successfully implement cost-effective energy efficiency, water conservation, and renewable projects at Federal sites nationwide. The use of Utility Energy Services Contracts (UESC) to implement these projects is a key emphasis of FUPWG. The reported total capital in UESCs, invested by the Federal and private sector, is more than $\$ 1.6$ billion dollars. In addition to UESCs, forty-five utilities are currently offering more than $\$ 1$ billion in rebates and incentives to Federal customers.

MISSION FUPWG was established by the Department of Energy's (DOE), Federal Energy Management Program (FEMP) in the spring of 1994 to strengthen relationships and investments between Federal agencies, public utilities, and other energyrelated organizations.

VISION FUPWG meetings provide training, education, and networking opportunities for working group members, which includes public utilities, their Federal utility customers, and other energy-related organizations. Issues addressed include the identification, design, and implementation of cost-effective energy efficiency; water conservation; and renewable energy projects. FUPWG provides members with educational and technical assistance services that focus on energy-efficiency projects, utility services, renewable energy project opportunities, and other value-added services. FUPWG is committed to the highest standards of quality and objectivity in all its activities to assist Federal agencies in reducing the energy-related cost of doing business.

\section{Objectives}

FUPWG meets twice a year to:

- Exchange information on recent utility incentive program success stories and best management practices

- Discuss current Federal energy management programs and products

- Provide a forum for lessons learned regarding individual agency energy management programs and projects

- Collaborate to address issues and obstacles inhibiting successful energy projects (e.g., identifying solutions for specific financing issues) through subcommittees and facilitated breakout sessions

FUPWG's objectives are to enhance Federal outreach, training, and education on current issues:

- Training on Federal procurement practices and energy efficiency and renewable energy technologies

- Increasing awareness of services offered by utilities 
- Overcoming barriers to project implementation

- Identifying opportunities for public utilities to work more effectively with Federal agencies at specific sites to achieve mandated energy savings set forth in the Energy Policy Act of 2005 and Executive Order 13423

- Developing Alternative Financing Guidance Memoranda (AFGM) to clarify legislation and regulations impacting UESCs; AFGMs are published by the FEMP Interagency Energy Management Task Force

- Recording and reporting successfully implemented utility-related projects at Federal sites

- Preparing agencies to respond effectively to future electric utility industry changes

For more information, go to: http://www1.eere. energy.gov/femp/financing/uescs_fupwg.html
A Strong Energy Portfolio for a Strong America

Energy efficiency and clean, renewable energy will mean a stronger economy, cleaner environment, and greater energy independence for America. Working with a wide array of state, community, industry, and university partners, the U.S. Department of Energy's Office of Energy Efficiency and Renewable Energy invests in a diverse portfolio of energy technologies.

\section{For More Information}

David McAndrew, FUPWG Chair

DOE/FEMP

202-586-7722

david.mcandrew@ee.doe.gov

Leslie Nicholls, FUPWG Coordinator

Energetics Incorporated

202-479-2748 x 128

Inicholls@energetics.com
THTES OA

\section{Energy Efficiency} and Renewable Energy

Bringing you a prosperous future where energy is clean, abundant, reliable, and affordable

EERE Information Center 1-877-EERE-INF or 1-877-337-3463 www.eere.energy.gov/

Produced for the U.S. Department of Energy by the National Renewable Energy Laboratory, a DOE national laboratory.

DOE/G0-102007-2454

August 2007 